\title{
LINEAMENTI DI DIRITTO AMBIENTALE POLACCO, A CURA DI KAROLINA SZUMA, CONTRIBUTI DI BARTOSZ RAKOCZY, JAN SZUMA, ED. ARACNE, 2013 - RECENZJA WYDAWNICZA
} (TŁUMACZENIE Z WŁOSKIEGO - KAROLINA SZUMA**)

Znanym jest fakt ciągle rosnącej roli Polski w Unii Europejskiej i we wspólnocie międzynarodowej.

Na podstawie tego stwierdzenia, wskazać trzeba, że Karolina Szuma zaproponowała możliwość poznania polskiego prawa ochrony środowiska - problematyki będącej z pewnością obecnie aktualną i interesującą. Jako redaktor książki deklaruje we wstępie, że w książce zostanie nakreślony zarys polskiego

Professore associato di diritto internazionale nell'Univeristà degli Studi di Genova - professor nadzwyczajny prawa międzynarodowego Uniwersytetu w Genui.

** Doktor nauk prawnych, adiunkt EWSPA w Warszawie, radca prawny. 
prawa ochrony środowiska, a jej celem jest wprowadzenie do tej problematyki Czytelników włoskojęzycznych.

W pierwszym rozdziale o charakterze wprowadzającym zostały przedstawione fundamentalne zasady polskiej regulacji prawa ochrony środowiska wraz z odwołaniem się do poszczególnych elementów składających się na omawianą problematykę. Zwrócono uwagę na obowiązki zastrzeżone dla Polski wynikające $\mathrm{z}$ przepisów unijnych, których istnienie wynika z członkostwa tego państwa w UE. W opracowaniu zawarto również krytyczne uwagi odnośnie poziomu legislacji jawiącej się często jako mało stabilnej i powodującej wiele trudności $\mathrm{w}$ jej zastosowaniu w praktyce.

Praca zawiera również szereg konkretnych przykładów działań podejmowanych przez Polskę $\mathrm{w}$ ramach zapewnienia prawnej ochrony środowiska. Tym samym przytoczone zostały nowe przepisy dotyczące gospodarki odpadami i złego wykorzystywania środków finansowych (publicznych i prywatnych) w tym zakresie; wskazano na przepisy dotyczące gospodarki wodnej, ochrony i organizacji środowiska leśnego i na regulację prawa łowieckiego. W opracowaniu nie omieszkano podkreślić wzajemnej zależności analizowanych przepisów, których nie można zamknąć tylko w ramach prawa administracyjnego. Stąd nie brakuje również odesłań do innych gałęzi prawa polskiego.

Wśród najciekawszych rozdziałów jest z pewnością ten poświęcony odpowiedzialności za szkodę w środowisku i jej charakterowi, mianowicie - cywilnej, karnej i administracyjnej - uregulowanej, jednak nie w całości w ustawie Prawo ochrony środowiska. Ostatnia z wymienionych kategorii stanowi element unijnej zasady prewencji jako podstawy weryfikacji odpowiedzialności. Szczególnie interesującą wydaje się być instytucja nakazująca wykonanie różnych obowiązków o cechach "ostrożności" (obowiązki wynikające z działu III, tytułu VI ustawy Prawo ochrony środowiska). Jest ona bardzo potężnym narzędziem do ochrony środowiska jako dobra wspólnego.

Opracowanie kończą rozważania na temat problematyki organizmów genetycznie zmodyfikowanych, której Polska poświęca odrębny akt rangi ustawowej regulujący wykorzystywa3/2014 nie i rozpowszechnianie tych organizmów, w tym zamierzone 
uwolnienie organizmów genetycznie zmodyfikowanych do środowiska, które nie jest zabronione. Trzeba zauważyć, że prawodawstwo unijne nie zostało prawidłowo implementowane przez legislatora polskiego, ponieważ dyrektywa 2001/18 nie może być bezpośrednio stosowana w krajowym porządku prawnym.

Książkę kończy bibliografia w większości zawierająca pozycje napisane w języku polskim. Publikacja potwierdza stwierdzenie wskazujące, że jej celem jest pogłębienie znajomości polskiego porządku prawnego ochrony środowiska u wszystkich Czytelników, którzy nie znają języka polskiego i w tym sensie stanowi bez wątpienia użyteczne źródło wiedzy.

Kontakt e-mail:

karolinaszuma@gmail.com 